\title{
Pengungkapan Sustainability Report dan Nilai Perusahan: Studi Empiris di Indonesia dan Singapura
}

\author{
Tedy Kurniawan, Hafiez Sofyani*, Evi Rahmawati \\ Universitas Muhammadiyah Yogyakarta \\ *hafiez.sofyani@umy.ac.id
}

\begin{abstract}
The categories of sustainability report disclosure consist of economic, environment, and social. This research aims to examine the influence of each categories of sustainability report disclosure on firm value. This research use secondary data from all companies that listed on Indonesia Stock Exchange and Singapore Stock Exchange in 2014-2016. There are 116 samples that obtained from purposive sampling method. The results of this research show that only economic category of sustainability report has positive influence on firm value in Indonesia and Singapore. The environment category of sustainability report has negative influence on firm value, while the social category doesn't have influence on firm value. The result of this research indicate that sustainability report disclosure which reported appropriately with choosen standard, especially in economic category will be useful to increase firm value in the point of view of investors.
\end{abstract}

Keywords: sustainability report, GRI-G4, firm value

\begin{abstract}
ABSTRAK
Kategori dalam pengungkapan sustainability report terdiri dari ekonomi, lingkungan, dan sosial. Penelitian ini bertujuan untuk menguji pengaruh dari masing-masing kategori dalam pengungkapan sustainability report terhadap nilai perusahaan. Penelitian ini menggunaka data sekunder yang didapatkan dari seluruh perusahaan yang terdaftar dalam Bursa Efek Indonesia dan Singapore Stock Exchange pada 2014-2016. Terdapat 116 sampel yang dihasilkan dari metode purposive sampling. Hasil penelitian menunjukkan hanya kategori ekonomi dari pengungkapan sustainability report yang berpengaruh positif terhadap nilai perusahaan. Kategori lingkungan dalam pengungkapan sustainability report berpengaruh negatif terhadap nilai perusahaan, sedangkan kategori sosial tidak berpengaruh terhadap nilai perusahaan. Hasil penelitian ini mengindikasikan bahwa pengungkapan sustainability report yang dilakukan sesuai dengan standar yang dipilih oleh perusahaan, terutama dalam kategori ekonomi akan dapat bermanfaat untuk meningkatkan nilai perusahaan di mata investor.
\end{abstract}

Kata kunci: sustainability report, GRI-G4, nilai perusahaan

\section{PENDAHULUAN}

Pada zaman yang mengalami perubahan sangat cepat seperti sekarang, perusahaan dituntut untuk memperluas pengetahuan, melakukan inovasi yang baik, dan belajar untuk berkompetisi dengan cara yang baru (Dess dan Picken, 2000). Proses belajar adalah inti dari kemampuan perusahaan untuk menyesuaikan 
dengan perubahan cepat yang terjadi. Secara spesifik hal ini dilakukan dengan menyusun agenda pembangunan berkelanjutan di dalam perusahaan.

Pembangunan berkelanjutan merupakan salah satu bentuk tantangan perubahan bagi perusahaan. Inti dari konsep ini adalah melakukan proses pembangunan yang sesuai dengan kebutuhan generasi saat ini, dengan tetap mempertimbangkan bagaimana generasi mendatang juga dapat memenuhi kebutuhannya (WCED, 1987). Perusahaan harus memperhatikan tiga aspek penting yaitu planet, people, dan profit dalam melakukan usahanya. Sustainability reporting merupakan cara tepat yang dapat dilakukan oleh perusahan. Perusahaan yang mengungkapkan sustainability report berarti telah menunjukkan komitmen yang nyata terhadap isu-isu sosial dan lingkungan. Adanya pengungkapan sustainability report akan berdampak pada peningkatan kepercayaan masyarakat terhadap perusahaan sehingga dapat meningkatkan nilai perusahaan (Weber dkk., 2008).

Perusahaan melakukan pengungkapan sustainability report kategori sosial (Chariri dan Nugroho, 2009) dan ekonomi (Cahyandito, 2010) dengan tujuan untuk memperoleh legitimasi atau mendapat pengakuan atas kegiatan yang mereka lakukan oleh pihak luar. Dengan adanya penerimaan dan pengakuan dari masyarakat, harapannya adalah terjadi peningkatan citra perusahaan di mata investor, sehingga investor akan lebih tertarik untuk berinvestasi pada saham perusahaan, dan pada akhirnya nilai perusahaan akan meningkat dengan adanya pengungkapan ini (Nurdin dan Cahyandito, 2006).

Peraturan terkait dengan pertanggungjawaban di bidang lingkungan dan sosial terdapat pada Undang-Undang Nomor 40 Tahun 2007, tentang Perseroan Terbatas. Selain itu, di dalam PSAK Nomor 1, Revisi Tahun 1998, tentang penyajian laporan keuangan, dinyatakan bahwa perusahaan dapat menyajikan laporan tambahan, misalnya laporan mengenai lingkungan hidup, khususnya bagi perusahaan dimana faktor lingkungan hidup memegang peranan penting dalam kegiatan usahanya.

Selain aturan-aturan yang berkaitan dengan sustainability report, sejak tahun 2005, di Indonesia juga terdapat penghargaan yang dianugerahkan kepada perusahaan atau organisasi yang telah mengembangkan dan mengungkapkan laporan keberlanjutan dan laporan pertanggungjawaban sosial dengan memanfaatkan website perusahaan, yang disebut dengan Sustainability Reporting Award (SRA). Penghargaan ini diharapkan dapat mendorong usaha yang lebih besar dalam hal mengomunikasikan keberlanjutan perusahaan, meningkatkan reputasi perusahaan, dan menunjukkan kepedulian perusahaan terhadap sesama manusia dan lingkungan sekitar. 
Berdasarkan data yang terdapat dalam Press Release SRA 2016, pada tahun 2005 hanya terdapat satu perusahaan di Indonesia yang mengungkapkan sustainability report, namun jumlahnya terus mengalami peningkatan hingga menjadi 120 perusahaan pada tahun 2016. Menurut Sarwono Kusumaatmadja, mantan Menteri Lingkungan Hidup dan ketua dewan juri pada SRA 2016, Indonesia hendaknya mencontoh Singapore Stock Exchange (SGX) dalam hal aturan yang mewajibkan anggota bursa menerbitkan sustainability report. Hal ini dilakukan karena dengan adanya pengungkapan sustainability report, para investor dapat memperkirakan tingkat keamanan untuk berinvestasi dalam kaitannya dengan risiko lingkungan dan sosial (Press Release SRA, 2016).

Pada aturan sustainability report di Singapura, basis "comply or explain", mengatur bahwa semua perusahaan yang terdaftar di Singapore Stock Exchange harus menggambarkan praktik keberlanjutan mereka berdasarkan lima komponen utama. Jika sebuah perusahaan tidak mengeluarkan satu saja komponen utama, maka perusahaan tersebut harus menjelaskan apa yang mereka lakukan sebagai gantinya dan mengapa melakukan hal tersebut (SGX News Releases).

Setelah melihat fenomena yang terjadi bahwa sustainability report di Indonesia masih bersifat voluntary, sedangkan di Singapura mulai akhir tahun 2017 laporan ini mulai bersifat mandatory, hal ini menunjukkan tentang adanya manfaat yang didapatkan oleh perusahaan sehingga mereka bersedia untuk melakukan pengungkapan ini. Salah satu manfaat dari pengungkapan sustainability report ini dan juga merupakan fokus dalam penelitian ini adalah dalam hal nilai perusahaan.

Penelitian yang melakukan pengujian terkait dengan pengaruh pengungkapan sustainability report terhadap nilai perusahaan telah beberapa kali dilakukan yakni oleh Astuti dan Juwenah (2017), Fatchan dan Trisnawati (2016), Gunawan dan Mayangsari (2015) dan Ramadhani (2016). Dari beberapa hasil riset terdahulu, masih terdapat beberapa research gap diantara penelitian-penelitian tersebut. Pertama, penggunaan harga saham penutupan perusahaan per 31 Desember sebagai pengukur nilai perusahaan pada penelitian Astuti dan Juwenah (2017).

Kedua, dalam hal sampel yang digunakan dalam penelitian. Astuti dan Juwenah (2017), menggunakan sampel yang terbatas pada perusahaan yang terdaftar dalam LQ 45 dan penggunaan sampel perusahaan kategori high-profile pada penelitian Ramadhani (2016). Ketiga, tahun pengamatan yang digunakan dalam penelitian di atas menggunakan tahun yang sama dalam mengukur pengaruh sustainability report dan nilai perusahaan. Hanya pada penelitian Ramadhani (2016), terdapat lag sebanyak satu tahun antara tahun pengukur 
pengungkapan sustainability report dan tahun pengukur nilai perusahaan. Research gap yang terdapat dalam beberapa penelitian di atas menunjukkan bahwa penelitian terkait pengaruh pengungkapan sustainability report menarik dan perlu untuk dilakukan pengujian kembali.

Fokus utama dalam penelitian ini adalah untuk menguji pengaruh pengungkapan sustainability report terhadap nilai perusahaan. Penelitian terdahulu hanya melakukan pengujian pada perusahaan dalam satu negara, sedangkan penelitian ini akan melakukan pengujian pada dua negara yaitu Indonesia dan Singapura. Alasan pemilihan dua negara ini adalah, yang pertama sifat dari sustainability reporting di Indonesia masih merupakan voluntary disclosure. Adapun Singapura, dapat dijadikan tolok ukur keberhasilan dari tujuan utama sustainability reporting. Hal ini tercermin dari keputusan terakhir Singapore Stock Exchange yang pada akhir 2017 telah memutuskan untuk meningkatkan level pengungkapan ini menjadi mandatory. Penelitian ini juga menguji apakah terdapat perbedaan luas pengungkapan antara perusahaan yang terdaftar dalam Bursa Efek Indonesia dan Singapura pada tahun 2014-2016.

\section{TINJAUAN PUSTAKA DAN PENGEMBANGAN HIPOTESIS Teori Stakeholder}

Teori ini menjelaskan bahwa sebuah perusahaan harus bertanggung jawab kepada pihak-pihak yang memiliki kepentingan terhadap perusahaan tersebut. Perusahaan harus membina hubungan baik dengan para pemangku kepentingan ini. Donaldson dan Preston (1995) mendukung teori ini dengan berpendapat bahwa teori stakeholder akan memperluas tanggung jawab perusahaan kepada seluruh pemangku kepentingan (stakeholders), bukan hanya kepada para pemilik saham perusahaan (shareholders).

Perusahaan harus melakukan upaya yang nyata untuk menjaga hubungan baik dengan para stakeholders, dengan cara mengamodasikan keinginan dan kebutuhan para stakeholders yang ada, terutama para stakeholders yang berhubungan langsung dengan sumber daya yang digunakan oleh perusahaan dalam aktivitas operasionalnya, misalnya tenaga kerja, konsumen, dan pemilik saham (Chariri dan Ghozali, 2007). Salah satu cara yang dapat dilakukan perusahaan untuk membina dan meningkatkan hubungan baik dengan para stakeholders adalah dengan mengungkapkan laporan yang mepunyai nilai tambah, yaitu sustainability report (Weber dkk., 2008).

\section{Teori Legitimasi}

Menurut Deegan (2002) dalam Tilling (2004), legitimasi merupakan pengakuan tentang legal atau tidaknya sesuatu. Teori legitimasi menjelaskan 
bahwa perusahaan dituntut untuk melakukan upaya-upaya untuk memastikan bahwa perusahaan telah melakukan kegiatan operasionalnya berdasarkan norma atau aturan yang terdapat dalam lingkungan masyarakat. Hal ini dilakukan agar status perusahaan, dan semua kegiatan operasional perusahaan dapat dikatakan sah dan diterima oleh pihak di luar perusahaan.

Legitimasi bertujuan untuk menyamakan asumsi dan persepsi bahwa semua kegiatan yang dilakukan perusahaan merupakan suatu hal yang diinginkan, pantas, dan sesuai dengan norma yang secara umum berlaku di dalam kehidupan sosial (Suchman, 1995). Menurut Chariri dan Ghozali (2007), hal yang menjadi landasan adanya teori ini adalah kontrak sosial yang terjadi dan disepakati bersama antara pihak perusahaan dan masyarakat dimana perusahaan beroperasi dengan menggunakan sumber daya di wilayah tersebut. Pengungkapan sustainability report yang dilakukan perusahaan merupakan salah satu usaha untuk membangun citra positif, bahwa perusahaan peduli terhadap permasalahan lingkungan dan sosial. Dengan melakukan hal ini, perusahaan berusaha untuk memperoleh legitimasi dari para stakeholders.

\section{Pengungkapan Sustainability Report Kategori Ekonomi dan Nilai Perusahaan.}

Di dalam melakukan investasi, para investor selalu berkaitan dengan dua hal, pertama adalah mengharapkan keuntungan, dan yang kedua adalah bersiap menghadapi semua risiko yang menyertainya. Oleh karena itu, investor membutuhkan transparansi informasi mengenai kinerja ekonomi perusahaan. Menurut Cahyandito (2010), adanya transparansi yang terdapat dalam sustainability report kategori ekonomi, akan dapat meningkatkan citra perusahaan dan kepercayaan stakeholders terhadap perusahaan. Hal ini secara langsung akan dapat menjaga hubungan baik antara perusahaan dan stakeholders termasuk investor, sehingga nilai perusahaan di mata investor akan meningkat dengan adanya pengungkapan ini. Hal ini sejalan dengan penelitian yang dilakukan oleh Astuti dan Juwenah (2017), yang menemukan bahwa pengungkapan kinerja ekonomi berpengaruh positif signifikan terhadap nilai perusahaan.

Dengan adanya pengungkapan kinerja ekonomi sebagai salah satu bentuk transparansi perusahaan kepada investor, akan dapat meningkatkan citra perusahaan di mata para investor. Hal ini akan berdampak pada kinerja keuangan perusahaan, salah satunya adalah profitabilitas (Natalia dan Tarigan, 2014). Meningkatnya kinerja keuangan akan meningkatkan harga saham di pasar saham. Berdasarkan uraian di atas, maka hipotesis yang diajukan dalam penelitian ini adalah: 


\section{H1: Pengungkapan sustainability report kategori ekonomi berpengaruh positif terhadap nilai perusahaan di Indonesia.}

H2: Pengungkapan sustainability report kategori ekonomi berpengaruh positif terhadap nilai perusahaan di Singapura.

\section{Pengungkapan Sustainability Report Kategori Lingkungan dan Nilai Perusahaan.}

Di era pembangunan berkelanjutan, perusahaan dituntut untuk melakukan pengungkapan terhadap kinerja lingkungan dimana perusahaan tersebut didirikan. Kinerja lingkungan ini akan menunjukkan sejauh mana perusahaan kepedulian perusahaan terhadap lingkungan sesuai dengan norma dan nilai yang berlaku secara umum dimana perusahaan tersebut berdiri. Perusahaan yang memiliki kinerja lingkungan yang baik tentunya akan meningkatkan kepercayaan investor untuk menginvestasikan dananya pada perusahaan tersebut (Nurdin dan Cahyandito, 2006).

Selain berdampak pada meningkatnya kepercayaan investor, pandangan masyarakat tentang aktivitas perusahaan pun akan semakin baik. Dengan meningkatnya citra perusahaan di mata investor dan juga masyarakat, hal ini akan berdampak pula pada meningkatnya nilai perusahaan. Hal ini sesuai dengan penelitian yang dilakukan oleh Natalia dan Tarigan (2014), bahwa kinerja lingkungan dapat berpengaruh terhadap meningkatnya profitabilitas perusahaan. Hal ini akan dapat berujung pada meningkatnya nilai perusahaan tersebut. Berdasarkan uraian di atas, maka hipotesis yang diajukan dalam penelitian ini adalah:

H3: Pengungkapan sustainability report kategori lingkungan berpengaruh positif terhadap nilai perusahaan di Indonesia.

H4: Pengungkapan sustainability report kategori lingkungan berpengaruh positif terhadap nilai perusahaan di Singapura.

\section{Pengungkapan Sustainability Report Kategori Sosial dan Nilai Perusahaan.}

Kategori sosial dalam sustainability report menyangkut dampak organisasi terhadap masyarakat dimana perusahaan tersebut beroperasi, dan menjelaskan risiko dari interaksi dengan institusi sosial lainnya yang mereka kelola. Kepedulian perusahaan dalam mengantisipasi isu-isu terkait masyarakat seperti komunitas, korupsi, kebijakan publik, anti kompetitif seperti anti-trust dan monopoli akan menjadi nilai lebih di mata investor. Pengungkapan sustainability report kategori sosial akan berdampak pada persepsi stakeholders tentang perlakuan perusahaan terhadap sumber daya manusia di sekitarnya (Simbolon dan Sueb, 2016). 
Pengungkapan sustainability report kategori sosial akan menunjukkan kepedulian perusahaan terhadap hak asasi manusia, praktik ketenagakerjaan yang baik, kenyamanan bekerja para tenaga kerja, dan juga tanggung jawab atas produk yang dihasilkan perusahaan. Dengan kepedulian perusahaan di lingkup sosial ini, nantinya akan meningkatkan citra perusahaan di mata para stakeholders (Tarigan dan Semuel, 2015), dan pada akhirnya akan berpengaruh pada nilai perusahaan. Berdasarkan uraian di atas, maka hipotesis yang diajukan dalam penelitian ini adalah:

H5: Pengungkapan sustainability report kategori sosial berpengaruh positif terhadap nilai perusahaan di Indonesia.

H6: Pengungkapan sustainability report kategori sosial berpengaruh positif terhadap nilai perusahaan di Singapura.

\section{Perbandingan Luas Pengungkapan Sustainability Report Antara Indonesia dan Singapura.}

Kebijakan dan peraturan mengenai pengungkapan sustainability report di Indonesia dan Singapura menurut CSR Asia dan GRI (2016), sebenarnya memiliki kondisi yang hampir sama. Kedua negara ini sama-sama memiliki kebijakan hukum yang mengatur tentang pengungkapan. Di Indonesia terdapat satu indeks sustainability yaitu Indeks SRI-KEHATI, sedangkan di Singapura juga telah terdapat indeks sustainability yaitu SGX Sustainability Indices. Webb, Cahan, dan Sun (2008) meneliti hubungan antara globalisasi dengan pengungkapan sukarela yang dikaitkan pada lingkungan hukum negara asal perusahaan. Perusahaan yang berasal dari lingkungan hukum kuat (common law system) mendapatkan tekanan yang lebih besar dibandingkan perusahaan dari lingkungan hukum lemah (civil law system), dalam kaitannya dengan melakukan pengungkapan yang baik. Indonesia sebagai penganut civil law system, sedangkan Singapura sebagai penganut common law system.

Adanya tekanan yang lebih besar di negara Singapura dibandingkan Indonesia dalam melakukan pengungkapan yang lebih baik, maka dapat dikatakan pengungkapan sustainability report di Singapura lebih baik daripada Indonesia. Hal ini diperkuat dengan adanya keputusan Singapore Stock Exchange yang akan mengubah status laporan ini menjadi mandatory di akhir 2017. Hal ini menunjukkan bahwa selain tuntutan yang lebih kuat di Singapura, luas pengungkapan dan manfaat yang didapatkan dari pengungkapan ini, salah satunya dampak pada nilai perusahaan juga mungkin berbeda. Berdasarkan uraian di atas, maka hipotesis yang diajukan dalam penelitian ini adalah:

H7: Terdapat perbedaan luas pengungkapan sustainability report antara Indonesia dan Singapura. 


\section{METODE PENELITIAN}

\section{Populasi dan Sampel}

Populasi dalam penelitian ini adalah semua perusahaan yang terdaftar di Bursa Efek Indonesia, dan Singapore Stock Exchange periode 2014-2016. Pemilihan sustainability report pada tahun 2014 dan 2015 dikarenakan sebagian besar perusahaan di Indonesia dan Singapura telah menggunakan pedoman GRIG4 yang merupakan pedoman terbaru yang dikeluarkan GRI. Teknik pengambilan sampel dalam penelitian ini adalah purposive sampling, yakni berdasarkan pertimbangan tertentu.

Kriterian pemilihan sampel adalah sebagai berikut: (1) Perusahaan yang terdaftar di Bursa Efek Indonesia dan Singapore Stock Exchange yang menerbitkan sustainability report pada tahun 2014 dan 2015, yang bersifat standalone report dan menggunakan standar GRI-G4; (2) Perusahaan yang terdaftar di Bursa Efek Indonesia dan Singapore Stock Exchange yang menerbitkan annual report pada tahun 2015 dan 2016; (3) Perusahaan tersebut menerbitkan sustainability report dan annual report yang terpublikasi.

\section{Jenis dan Sumber Data}

Jenis data yang digunakan dalam penelitian ini adalah data sekunder, yang terdiri dari sustainability report tahun 2014-2015 dan annual report tahun 20152016 dari perusahaan yang telah terdaftar di Bursa Efek Indonesia dan Singapore Stock Exchange. Terdapat lag sebanyak satu tahun dalam penelitian ini yang bertujuan untuk lebih dapat melihat dampak yang ditimbulkan dengan diterbitkannya sustainability report, terhadap nilai perusahaan.

Tabel 1. Prosedur Pemilihan Sampel di Indonesia

\begin{tabular}{clcr}
\hline No & \multicolumn{1}{c}{ Uraian } & Perusahaan & Jumlah Data \\
\hline 1 & $\begin{array}{l}\text { Perusahaan yang terdaftar di Bursa Efek } \\
\text { Indonesia yang menerbitkan sustainability report }\end{array}$ & & \\
& $\begin{array}{l}\text { dan annual report pada tahun 2014 dan 2015 } \\
2\end{array}$ & 40 & 80 \\
& $\begin{array}{l}\text { Perusahaan yang menerbitkan dua laporan di atas } \\
\text { namun tidak sesuai dengan kriteria yang }\end{array}$ & & \\
& ditetapkan & 1 & $(2)$ \\
$3 \quad$ Data Oulier & 2 & $(4)$ \\
\hline Total Sampel dalam Penelitian & & $\mathbf{7 4}$ \\
\hline
\end{tabular}

Data annual report dan sustainability report diperoleh dengan cara mengakses langsung website resmi perusahaan. Annual report juga dapat diperoleh dari website Bursa Efek Indonesia (www.idx.co.id), dan Singapore 
Stock Exchange (www.sgx.com). Adapun untuk sustainability report juga dapat diperoleh dari database Global Reporting Initiative (GRI).

Tabel 2. Prosedur Pemilihan Sampel di Singapura

\begin{tabular}{clrr}
\hline No & \multicolumn{1}{c}{ Uraian } & Perusahaan & Jumlah Data \\
\hline $1 \quad$ & Perusahaan yang terdaftar di Singapore Stock & & \\
& $\begin{array}{l}\text { Exchange yang menerbitkan sustainability } \\
\text { report dan annual report pada tahun 2014 dan }\end{array}$ & & \\
& 2015 & 27 & 54 \\
$2 \quad$ & & \\
& $\begin{array}{l}\text { Perusahaan yang menerbitkan dua laporan di } \\
\text { atas namun tidak sesuai dengan kriteria yang } \\
\quad \text { ditetapkan }\end{array}$ & 5 & $(10)$ \\
$3 \quad$ Data Oulier & 1 & $(2)$ \\
\hline Total Sampel dalam Penelitian & & $\mathbf{4 2}$ \\
\hline
\end{tabular}

\section{Definisi Operasional Variabel Penelitian}

Variabel dependen di dalam penelitian ini adalah nilai perusahaan yang diproksikan dengan rasio Tobin's $Q$. Pemilihan proksi ini berdasarkan pertimbangan yakni rasio ini telah populer digunakan di dalam penelitian terdahulu dan merupakan proksi yang tepat dalam mengukur nilai perusahaan (Sudiyatno dan Puspitasari, 2010). Formulasi rasio Tobin's Q dapat dilihat pada Rumus 1.

$$
\text { Tobin's } Q=\frac{\text { Total Market Value of Firm }}{\text { Total Asset Value }}
$$

Rumus 1 diuraikan lagi seperti penelitian Ali, Mahmud, dan Lima (2016) menjadi Rumus 2.

$$
\text { Tobin's } Q=\frac{\text { Equity Market Value+Liabilities Market Value }}{\text { Equity BookValue+Liabilities Book Value }}
$$

Berdasarkan asumsi yang sering digunakan, nilai dari liabilities market value adalah sama dengan liabilitie book value. Penelitian ini lebih berfokus pada nilai perusahaan dari sudut pandang investor, sehingga rumus Tobin's $Q$ yang digunakan di dalam penelitian ini adalah seperti yang tertera pada Rumus 3.

$$
\text { Tobin's } Q=\frac{\text { Equity Market Value }(E M V)}{\text { Equity Book Value }(E B V)}
$$

Keterangan:

$E M V=$ Harga saham per lembar dikalikan dengan jumlah saham yang beredar.

$E B V=$ Total aset dikurangi dengan total kewajiban. 
Interpretasi dari skor Tobin's $Q$ adalah sebagai beikut: (1) Tobin's $Q<1$ menggambarkan bahwa saham dalam kondisi undervalued. Hal ini mengindikasikan bahwa manajemen telah gagal dalam mengelola aktiva perusahaan. Potensi pertumbuhan investasi rendah; (2) Tobin's $Q=1$ menggambarkan bahwa saham dalam kondisi average. Hal ini mengindikasikan bahwa manajemen stagnan dalam mengelola aktiva. Potensi pertumbuhan investasi tidak berkembang; dan (3) Tobin's $Q>1$ menggambarkan bahwa saham dalam kondisi overvalued. Hal ini mengindikasikan bahwa manajemen berhasil dalam mengelola aktiva perusahaan. Potensi pertumbuhan investasi tinggi.

Sedangkan variabel independen di dalam penelitian ini terdiri dari tiga variabel meliputi: (a) pengungkapan sustainability report kategori ekonomi, (b) pengungkapan sustainability report kategori lingkungan, (c) pengungkapan sustainability report kategori sosial. Variabel independen dalam penelitian ini akan dinyatakan dalam proksi yang sama yaitu SRDI atau Sustainability Report Disclosure Index. SRDI menilai tanggung jawab ekonomi, lingkungan, dan sosial yang sesuai dengan kriteria menurut Global Initiative Reporting (GRI) G4.

Teknik yang digunakan dalam melakukan input data adalah content analysis. Teknik ini merupakan pengkodefikasian teks yang mempunyai ciri-ciri yang akan ditulis dalam berbagai kelompok. Jika perusahaan mengungkapkan suatu item maka akan diberi nilai 1, sedangkan jika perusahaan tidak mengungkapkan suatu item maka akan diberi nilai 0. Perhitungan dapat menggunakan Rumus 4.

$$
S R D I=\frac{\text { Jumlah item yang diungkapkan. }}{\text { Jumlah item yang diharapkan diungkapkan. }}
$$

Jumlah item yang diungkapkan akan dihitung sesuai jumlah yang tertulis pada sustainability report masing-masing perusahaan. Sedangkan untuk jumlah item yang diharapkan diungkapkan, untuk kategori ekonomi sebanyak 9 item, kategori lingkungan sebanyak 34 item, dan kategori sosial sebanyak 48 item. Jadi total pengungkapan sustainability report yang diharapkan diungkapkan ada 91 item.

\section{Teknik Pengujian Hipotesis}

Pengujian hipotesis untuk model 1 pada penelitian ini akan dilakukan dengan uji regresi linear berganda. Untuk melakukan pengujian ini maka diperlukan uji koefisian determinasi dan uji signifikansi parameter individual atau ( $t$ test). Uji regresi linear berganda digunakan untuk menguji pengaruh dua atau lebih variabel independen terhadap variabel dependennya. Hubungan antar variabel tersebut dapat digambarkan dengan persamaan pada Rumus 5. 


$$
F V=\alpha+\beta 1 E C+\beta 2 E N+\beta 5 S O+e
$$

Keterangan:

$\mathrm{FV}=$ Nilai Perusahaan

EC = Pengungkapan sustainability report kategori ekonomi

$\mathrm{EN}=$ Pengungkapan sustainability report kategori lingkungan

$\mathrm{SO}=$ Pengungkapan sustainability report kategori sosial

$\alpha=$ konstanta persamaan regresi

$\beta=$ koefisien regresi tiap variabel

e $=$ error

Pengujian hipotesis untuk model 2 pada penelitian ini akan dilakukan dengan uji beda sampel independen (independent sample t-test). Uji ini dilakukan untuk mengetahui apakah dari dua sampel yang tidak berhubungan memiliki nilai rata-rata yang berbeda atau tidak.

\section{HASIL ANALISIS STATISTIK DESKRIPTIF Gambaran Umum Objek Penelitian}

Penelitian ini menggunakan sampel seluruh perusahaan yang terdaftar di Bursa Efek Indonesia (BEI) dan Singapore Stock Exchange (SGX) yang menerbitkan sustainability report dan annual report 2014-2016. Berdasarkan kriteria-kriteria dalam purposive sampling yang telah ditetapkan pada sebelumnya, maka diperoleh sampel berjumlah 37 perusahaan di Indonesia, dan 21 perusahaan di Singapura (Lihat Tabel 1 dan Tabel 2).

\section{Analisis Statistik Deskriptif}

Hasil analisis statistik deskriptif untuk model penelitian 1 ditunjukkan pada Tabel 3 dan 4 .

Tabel 3. Statistik Deskriptif di Indonesia

\begin{tabular}{lccccc}
\hline & & & & & Std. \\
& N & Minimum & Maximum & Mean & Deviation \\
\hline EC_INA & 74 & 0,111 & 1,000 & 0,54957 & 0,234895 \\
EN_INA & 74 & 0,029 & 0,971 & 0,34384 & 0,242073 \\
SO_INA & 74 & 0,104 & 0,938 & 0,35400 & 0,205921 \\
EES_INA & 74 & 0,099 & 0,956 & 0,36965 & 0,198288 \\
FV_INA & 74 & 0,051 & 3,889 & 1,41176 & 0,980848 \\
Valid N (listwise) & 74 & & & & \\
\hline
\end{tabular}


Tabel 4. Statistik Deskriptif di Singapura

\begin{tabular}{lccccc}
\hline & N & Minimum & Maximum & Mean & $\begin{array}{c}\text { Std. } \\
\text { Deviation }\end{array}$ \\
\hline EC_SIN & 42 & 0,111 & 1,000 & 0,30143 & 0,201377 \\
EN_SIN & 42 & 0,059 & 0,765 & 0,35086 & 0,182390 \\
SO_SIN & 42 & 0,083 & 0,646 & 0,33143 & 0,138257 \\
EES_SIN & 42 & 0,099 & 0,670 & 0,33590 & 0,142394 \\
FV_SIN & 42 & 0,316 & 8,417 & 1,68090 & 1,902557 \\
Valid N (listwise) & 42 & & & & \\
\hline
\end{tabular}

\section{HASIL PENGUJIAN HIPOTESIS}

Uji pendahuluan untuk menguji kualitas data yang akan digunakan di dalam penelitian ini adalah uji asumsi klasik, kemudian dilanjutkan pengujian hipotesis dengan melakukan regresi linear berganda untuk model penelitian 1 . Adapun model penelitian 2 akan dilakukan dengan uji beda sampel independen (independent sample t-test). Pengujian asumsi klasik yang dilakukan pada model persamaan penelitian ini meliputi uji multikolinearitas, uji autokorelasi, uji heteroskedastisitas, dan uji normalitas. Dari hasil uji asumsi klasik didapatkan simpulan bahwa data telah memenuhi uji asumsi klasik, sehingga pengujian dengan analisis regresi dapat dilakukan.

Tabel 5. Hasil Regresi Model Penelitian 1 - Indonesia

\begin{tabular}{lccc}
\hline \multicolumn{1}{c}{ Variabel } & $\boldsymbol{\beta}$ & P-Value & \multicolumn{1}{c}{ Kesimpulan } \\
\hline EC_INA & 2,250 & 0,000 & Berpengaruh positif \\
EN_INA & $-1,341$ & 0,032 & Berpengaruh negatif \\
SO_INA & $-0,453$ & 0,553 & Tidak berpengaruh \\
\hline Adjusted R ${ }^{2}$ & & & 0,159 \\
F Statistic & & & 5,588 \\
Probability (F Statistic) & & & 0,002 \\
\hline
\end{tabular}

Hasil pengujian hipotesis model penelitian 1, disajikan pada Tabel 5 untuk sampel perusahaan di Indonesia, sedangkan untuk sampel perusahaan di Singapura akan disajikan pada Tabel 6. Hasil pengujian hipotesis model penelitian 2 disajikan pada Tabel 7. Berdasarkan Tabel 5, didapatkan hasil bahwa nilai koefisien determinasi (adjusted $R^{2}$ ) dengan sampel perusahaan di Indonesia adalah 0,159 atau $15,9 \%$. Hal ini menunjukkan bahwa variabel pengungkapan sustainability report kategori ekonomi (EC_INA), kategori lingkungan (EN_INA), dan kategori sosial (SO_INA) dapat memengaruhi variabel nilai perusahaan (FV_INA) sebesar 15,9\%. Adapun sisanya sebesar 84,1\% dipengaruhi oleh variabel lain di luar model penelitian. 
Tabel 6. Hasil Regresi Model Penelitian 1 - Singapura

\begin{tabular}{lccc}
\hline \multicolumn{1}{c}{ Variabel } & $\boldsymbol{\beta}$ & P-Value & \multicolumn{1}{c}{ Kesimpulan } \\
\hline EC_SIN & 6,487 & 0,000 & Berpengaruh positif \\
EN_SIN & $-4,210$ & 0,043 & Berpengaruh negatif \\
SO_SIN & $-2,545$ & 0,372 & Tidak berpengaruh \\
\hline Adjusted R & & & 0,537 \\
F Statistic & & & 16,823 \\
Probability (F Statistic) & & & 0,000 \\
\hline
\end{tabular}

Tabel 7. Hasil Uji Beda antara Indonesia dan Singapura

\begin{tabular}{lccccc}
\hline & \multicolumn{3}{c}{$\begin{array}{c}\text { Levene's Test for } \\
\text { Equality of Variances }\end{array}$} & \multicolumn{3}{c}{ t-test for Equality of Means } \\
\cline { 2 - 7 } & $\mathrm{F}$ & Sig. & $\mathrm{t}$ & $\mathrm{df}$ & Sig. (2-tailed) \\
\cline { 2 - 7 } & 4,576 & 0,035 & 0,969 & 114 & 0,334 \\
$\begin{array}{l}\text { Equal variances assumed } \\
\begin{array}{l}\text { Equal variances not } \\
\text { assumed }\end{array}\end{array}$ & & & & & \\
\hline
\end{tabular}

Berdasarkan Tabel 6, didapatkan hasil bahwa nilai koefisien determinasi (adjusted $R^{2}$ ) dengan sampel perusahaan di Singapura adalah 0,537 atau 53,7\%. Hal ini menunjukkan bahwa variabel pengungkapan sustainability report kategori ekonomi (EC_SIN), kategori lingkungan (EN_SIN), dan kategori sosial (SO_SIN) dapat memengaruhi variabel nilai perusahaan (FV_SIN) sebesar 53,7\%. Adapun sisanya sebesar $46,3 \%$ dipengaruhi oleh variabel lain di luar model penelitian. Berdasarkan Tabel 7, didapatkan hasil bahwa nilai $F$ pada Levene's test for equality of variances sebesar 4,576 dengan signifikansi sebesar 0,035, maka dinyatakan bahwa data tidak homogen. Hal selanjutnya yang dilakukan adalah melihat nilai sig. (2-tailed) pada baris equal variances not assumed. Nilai sig. (2tailed) yang ditunjukkan sebesar 0,292 > $\alpha(0,05)$, maka dapat disimpulkan tidak adanya perbedaan signifikan antara Indonesia dan Singapura.

Berdasarkan Tabel 5, diketahui bahwa pengungkapan sustainability report kategori ekonomi memiliki koefisien regresi yang arahnya positif sebesar 2,250 dengan nilai signifikansi sebesar $0,000<\alpha(0,05)$. Dengan demikian dapat disimpulkan bahwa hipotesis pertama $\left(\mathrm{H}_{1}\right)$ yang menyatakan bahwa pengungkapan sustainability report kategori ekonomi berpengaruh positif terhadap nilai perusahaan di Indonesia dinyatakan diterima. Berdasarkan Tabel 6, ditunjukkan bahwa pengungkapan sustainability report kategori ekonomi memiliki koefisien regresi yang arahnya positif sebesar 2,045 dengan nilai signifikansi sebesar $0,000<\alpha(0,05)$. Dengan demikian dapat disimpulkan bahwa hipotesis kedua $\left(\mathrm{H}_{2}\right)$ yang menyatakan bahwa pengungkapan sustainability report 
kategori ekonomi berpengaruh positif terhadap nilai perusahaan di Singapura dinyatakan diterima. Hasil ini mengndikasikan bahwa di dalam melakukan investasi, para investor akan selalu berhadapan dengan dua hal, yang pertama adalah harapan keuntungan yang diharapkan dan yang kedua adalah risiko yang selalu menyertai berbagai keputusan mereka. Oleh karena itu, transparansi dalam hal kondisi ekonomi perusahaan merupakan salah satu hal yang akan menjadi pertimbangan para investor dalam mengambil keputusan untuk melakukan investasi.

Dengan adanya pengungkapan kinerja ekonomi sebagai salah satu bentuk transparansi perusahaan kepada investor, akan dapat meningkatkan citra perusahaan di mata para investor dan menarik minat untuk berinvestasi pada saham perusahaan tersebut. Hal ini secara langsung akan dapat menjaga hubungan baik antara perusahaan dan stakeholders khususnya investor, sehingga nilai perusahaan di mata investor akan meningkat dengan adanya pengungkapan ini (Cahyandito, 2010). Hal ini sejalan dengan penelitian yang dilakukan oleh Astuti dan Juwenah (2017), yang menemukan bahwa pengungkapan kinerja ekonomi berpengaruh positif signifikan terhadap nilai perusahaan.

Berdasarkan Tabel 5, dapat diketahui bahwa pengungkapan sustainability report kategori lingkungan memiliki koefisien regresi yang arahnya negatif sebesar 1,341 dengan nilai signifikansi sebesar $0,032<\alpha(0,05)$. Sehingga dapat disimpulkan bahwa hipotesis ketiga (H3) yang menyatakan bahwa pengungkapan sustainability report kategori lingkungan berpengaruh positif terhadap nilai perusahaan di Indonesia dinyatakan ditolak. Berdasarkan Tabel 6, menunjukkan bahwa pengungkapan sustainability report kategori lingkungan memiliki koefisien regresi yang arahnya negatif sebesar 4,210 dengan nilai signifikansi sebesar $0,043<\alpha(0,05)$. Sehingga dapat disimpulkan bahwa hipotesis keempat (H4) yang menyatakan bahwa pengungkapan sustainability report kategori lingkungan berpengaruh positif terhadap nilai perusahaan di Singapura dinyatakan ditolak.

Hasil pengujian ini bertolak belakang dengan penelitian yang dilakukan oleh Natalia dan Tarigan (2014), yang menyatakan bahwa kinerja lingkungan dapat berpengaruh terhadap meningkatnya profitabilitas perusahaan. Dengan meningkatnya citra perusahaan di mata investor dan juga masyarakat, hal ini akan berdampak pada kinerja keuangan perusahaan yang akan dapat berujung pada meningkatnya nilai perusahaan tersebut. Namaun pada penelitian ini hal itu tidak terdukung.

Anomali yang terjadi seperti ini mungkin dapat disebabkan oleh beberapa hal. Pertama tentang belum diwajibkannya pelaporan ini di Indonesia. Hasil pencarian data membuktikan hanya sekitar 5\% perusahaan yang terdaftar di Bursa 
Efek Indonesia yang menerbitkan sustainability report. Besarnya persentase perusahaan yang belum melakukan pengungkapan ini mungkin secara tidak langsung dapat merugikan perusahaan yang telah memiliki pemikiran tentang sustainable developement. Keinginan beberapa perusahaan untuk meningkatkan citra perusahaan dengan mengungkapkan sustainability report kategori lingkungan mungkin dapat menjadi senjata makan tuan.

Fakta yang terjadi di Indonesia adalah kerusakan lingkungan yang semakin meningkat setiap tahunnya dan salah satu penyebabnya adalah aktivitas perusahaan. Dalam hal ini perusahaan yang belum melaporkan sustainability report khusunya kategori lingkungan tidak dapat terpantau dengan jelas oleh investor. Mindset para investor yang mungkin terbentuk adalah pengungkapan yang dilakukan beberapa perusahaan di Indonesia hanyalah untuk meningkatkan citra saja, dan bersifat kontradiktif dengan kenyataan bahwa lingkungan di Indonesia semakin memburuk. Hal ini lah yang mungkin dapat menyebabkan hubungan negatif antara pelaporan sustainability report kategori lingkungan terhadap nilai perusahaan.

Untuk penjelasan tentang anomali ini di Singapura salah satunya mungkin disebabkan oleh sedikitnya perusahaan di Singapura yang melakukan pengungkapan sesuai standar Global Reporting Initiative (GRI). Penyebab lain adalah kemungkinan bahwa periode penelitian ini merupakan waktu yang digunakan perusahaan yang terdaftar di Singapore Stock Exchange untuk menentukan langkah ke depannya, atau dapat dikatakan ini adalah masa transisi sebelum pelaporan ini diwajibkan di akhir tahun 2017. Selain itu, masa transisi ini mungkin digunakan oleh perusahaan dalam menentukan standar yang akan digunakan dalam pelaporan saat nanti sustainability report telah bersifat mandatory. Faktor lain yang mungkin dapat menyebabkan anomali ini adalah skeptisisme dari investor terkait dengan external assurance yang memang baik pada perusahaan di Indonesia maupun di Singapura tidak mewajibkan hal ini.

Berdasarkan Tabel 5, diketahui bahwa pengungkapan sustainability report kategori sosial memiliki koefisien regresi yang arahnya negatif sebesar 0,453 dengan nilai signifikansi sebesar $0,553>\alpha(0,05)$. Sehingga dapat disimpulkan bahwa hipotesis kelima (H5) yang menyatakan bahwa pengungkapan sustainability report kategori sosial berpengaruh positif terhadap nilai perusahaan di Indonesia dinyatakan ditolak. Berdasarkan Tabel 6, diketahui bahwa pengungkapan sustainability report kategori sosial memiliki koefisien regresi yang arahnya negatif sebesar 2,545 dengan nilai signifikansi sebesar 0,372> $>$ $(0,05)$. Sehingga dapat disimpulkan bahwa hipotesis keenam (H6) yang menyatakan bahwa pengungkapan sustainability report kategori sosial berpengaruh positif terhadap nilai perusahaan di Singapura dinyatakan ditolak. 
Kategori sosial dalam sustainability report berfokus pada hubungan langsung perusahaan dengan stakeholders yang terdiri dari pekerja dan masyarakat dalam hal ini khususnya konsumen. Hal ini menunjukkan bahwa pengungkapan kategori sosial tidak berhubungan langsung dengan kepentingan investor. Penelitian ini menggunakan sudut pandang investor sebagai hal utama, sehingga mungkin ini merupakan salah satu faktor mengapa pengungkapan sustainability report kategori sosial tidak berpengaruh terhadap nilai perusahaan. Hasil pengujian ini tidak sejalan dengan penelitian yang dilakukan Simbolon dan Sueb (2016), yang menyatakan pengungkapan sustainability report kategori sosial akan berdampak pada persepsi stakeholders tentang perlakuan perusahaan terhadap sumber daya manusia di sekitarnya sehingga akan menjadi nilai lebih di mata investor. Begitu pula dengan penelitian yang dilakukan oleh Tarigan dan Semuel (2015) yang menyatakan bahwa dengan adanya pengungkapan ini juga akan menurunkan tingkat perputaran karyawan sehingga dapat berujung pada meningkatnya produktivitas perusahaan.

Berdasarkan Tabel 7, didapatkan hasil bahwa nilai $F$ pada Levene's test for equality of variances sebesar 4,576 dengan signifikansi sebesar 0,035, maka dinyatakan bahwa data tidak homogen. Hal selanjutnya yang dilakukan adalah melihat nilai sig. (2-tailed) pada baris equal variances not assumed. Nilai sig. (2tailed) yang ditunjukkan sebesar 0,292 > $\alpha(0,05)$, maka dapat disimpulkan bahwa luas pengungkapan sustainability report antara perusahaan-perusahaan di negara Indonesia dan Singapura tidak memiliki perbedaan yang signifikan. Dengan demikian hipotesis ketujuh (H7) yang menyatakan bahwa terdapat perbedaan luas pengungkapan sustainability report di Indonesia dan Singapura dinyatakan ditolak.

Hasil pengujian hipotesis ketujuh menunjukkan bahwa tidak terdapat perbedaan yang signifikan dalam hal luas pengungkapan sustainability report antara perusahaan di Indonesia dan Singapura. Hal ini mungkin dapat disebabkan oleh beberapa faktor. Pertama, dari sisi Indonesia mungkin perusahaanperusahaan yang terdaftar di BEI telah memiliki mindset untuk memulai dan menjadikan pelaporan ini sebagai salah satu bentuk keunggulan kompetitif. Perusahaan mungkin menilai bahwa peluang untuk meningkatkan citra perusahaan semakin meningkat dengan adanya pelaporan ini, meskipun dampak dari usaha perusahaan untuk bersaing dengan para kompetitornya ini mungkin tidak berupa hasil instan yang terlihat di tahun berikutnya. Kedua, dari sisi Singapura, standar pelaporan yang ada di negara tersebut tidak hanya satu seperti di Indonesia yakni mengacu pada Global Reporting Initiative (GRI). Bentuk standar pelaporan di Singapura selain GRI, salah satunya adalah mengacu pada The Global Compact Network Singapore (GCNS) dalam bentuk Communication 
On Progress (COP). Selain itu terdapat pula perusahaan yang terdaftar di SGX yang mengungkapkan sustainability report dengan standar lain.

Hasil pengujian ini tidak sejalan dengan penelitian yang dilakukan oleh Webb, Cahan, dan Sun (2008), yang menyatakan bahwa perusahaan yang berasal dari lingkungan hukum kuat (common law system) mendapatkan tekanan yang lebih besar dibandingkan perusahaan dari lingkungan hukum lemah (civil law system). Indonesia sebagai penganut civil law system, sedangkan Singapura menganut common law system sehingga dalam hal luas pelaporan sustainability report dimungkinkan adanya perbedaan.

\section{KESIMPULAN, KETERBATASAN DAN SARAN}

Berdasarkan hasil analisis yang telah dilakukan, dapat ditarik beberapa kesimpulan, pertama, pengungkapan sustainability report kategori ekonomi berpengaruh positif terhadap nilai perusahaan, baik di Indonesia maupun di Singapura. Kedua, pengungkapan sustainability report kategori lingkungan berpengaruh negatif terhadap nilai perusahaan, baik di Indonesia maupun di Singapura. Ketiga, pengungkapan sustainability report kategori sosial tidak berpengaruh terhadap nilai perusahaan, baik di Indonesia maupun di Singapura. Keempat, Secara keseluruhan, baik kategori ekonomi, lingkungan, maupun sosial, pertimbangan investor tentang kredibilitas dari sustainability report juga mungkin dapat menjadi salah satu faktor. Kelima, tidak terdapat perbedaan yang signifikan pada luas pengungkapan sustainability report antara perusahaan yang terdaftar di Bursa Efek Indonesia dan Singapore Stock Exchange

Berdasarkan hasil penelitian ini terdapat beberapa implikasi penting, yakni: pertama, bagi regulator diharapkan dapat memberikan standar yang baku tentang pengungkapan sustainability report baik di Indonesia maupun di Singapura agar pelaksanaan pengungkapan dapat lebih terstruktur dan mudah untuk mengevaluasi serta melihat dampaknya salah satunya terhadap nilai perusahaan. Selain itu, pihak regulator juga diharapkan dapat menentukan pihak yang dapat berperan sebagai external assurance terkait dengan pelaporan ini, untuk meningkatkan akurasi dan kredibilitas dari sustainability report.

Kedua, bagi perusahaan diharapkan lebih memperhatikan pelaksanaan pengungkapan sustainability report terutama pada kategori ekonomi karena ditemukan hasil bahwa hal itu memengaruhi nilai perusahaan baik di Indonesia maupun di Singapura. Terakhir, bagi investor diharapkan lebih mempertimbangkan tentang pentingnya pengungkapan sustainability report kategori ekonomi sebagai pertimbangan dalam berinvestasi, serta sebagai wujud nyata investor dalam menjaga keberlanjutan ekonomi pada tingkat lokal, nasional, maupun global. 
Penelitian ini dilakukan dengan beberapa keterbatasan penelitian yang dengan keterbatasan tersebut dapat berpengaruh terhadap hasil penelitian. Pertama, penelitian ini hanya dilakukan dalam dua periode yaitu 2014-2015 dan 2015-2016. Anomali yang terjadi pada hipotesis ketiga dan keempat mungkin salah satunya dapat disebabkan oleh rentang waktu yang kurang panjang, sehingga pengaruh variabel independen terhadap variabel dependen dapat terganggu baik konsistensi arah maupun signifikansinya. Kedua, unsur subjektivitas yang tinggi dalam menentukan dan menganalisis sustainability report disclosure index (SRDI), karena tidak adanya penentuan baku yang dijadikan standar. Penelitian ini hanya menganalisis pengungkapan sustainability report yang menggunakan standar GRI-G4, sehingga pengungkapan dengan standar lain tidak masuk di dalam penelitian.

Berdasarkan keterbatasan tersebut, peneliti memiliki beberapa saran yang mungkin dapat digunakan untuk penelitian selanjutnya, antara lain sebagai berikut: pertama, penelitian selanjutnya mungkin dapat menambah periode penelitian, karena pengungkapan sustainability report merupakan pengungkapan untuk keberlanjutan dalam jangka panjang. Kedua, penelitian selanjutnya mungkin dapat memilih dan menganalisis Sustainability Reporting Disclosure Index (SRDI) berdasarkan standar selain GRI-G4 misalnya The Global Compact Network Singapore (GCNS), atau bahkan membandingkan standar mana yang terbaik.

\section{DAFTAR PUSTAKA}

Ali, M. R., Mahmud, M. S., dan Lima, R. P. (2016). Analyzing Tobin's Q Ratio of Banking Industry of Bangladesh: A Comprehensive Guideline for Investors. Asian Business Review, 6(2), 85-90.

Astuti, A. D., dan Juwenah. (2017). Pengaruh Pengungkapan Sustainability Report terhadap Nilai Perusahaan yang Tergabung dalam LQ 45 tahun 2012-2013. Accounthink - Journal of Accounting and Finance, 2(1), 301313.

Cahyandito, M. F. (2010). Pembangunan Berkelanjutan, Ekonomi dan Ekologi, Sustainability Communication dan Sustainability Reporting. Jurnal LMFE, (22), 1-12.

Chariri, A., dan Ghozali, I. (2007). Teori Akuntansi. Semarang: Badan Penerbit UNDIP. 
Chariri, A., dan Nugroho, F. A. (2009). Retorika dalam Pelaporan Corporate Social Responsibility: Analisis Semiotik Atas Sustainability Reporting PT Aneka Tambang Tbk. Simposiun Nasional Akuntansi, XII(5), 0-23.

CSR Asia, dan GRI. (2016). Sustainability Disclosure in ASEAN: The ASEAN Extractive Sector.

Database GRI. http://database.globalreporting.org/. Diakses pada Juli dan November 2017.

Dess, G. G., dan Picken, J. C. (2000). Changing Roles: Leadership in the 21st Century. Organizational Dynamics, 28(3): 18-34. Doi:10.1016/S00902616(00)88447-8

Donaldson, T. dan Preston, L. E. (1995). The Stakeholder Theory of The Corporation: Concepts, Evidence, Corporations and its Implications. Management, 20(1): 65-91. Doi:10.2307/258887.

Fatchan, I. N., dan Trisnawati, R. (2016). Pengaruh Good Governance Pada Hubungan Antara Sustainability Report dan Nilai Perusahaan (Studi Empiris Perusahaan Go Public Di Indonesia Periode 2014-2015). Riset Akuntansi Dan Keuangan Indonesia, 1(1): 25-34.

Global Reporting Initiative (GRI). Diakses Juli dan November 2017, dari https://www.globalreporting.org/.

Gunawan, Y., dan Mayangsari, S. (2015). Pengaruh Sustainability Reporting terhadap Nilai Perusahaan dengan Investment Opportunity Set sebagai Variabel Moderating. e-Journal Akuntansi Trisakti, (February: 1-12.

Indonesia. Undang-Undang tentang Perseroan Terbatas, UU No. 40 Tahun 2007.

Natalia, R., dan Tarigan, J. (2014). Pengaruh Sustainability Reporting Terhadap Kinerja Keuangan Perusahaan Publik Dari Sisi Profitability Ratio. Jurnal ekonomi, volume 22, 111-120. Doi:10.1017/CBO9781107415324.004.

Nurdin, E., dan Cahyandito, M. F. (2006). Pengungkapan Tema-Tema Sosial dan Lingkungan dalam Laporan Tahunan Perusahaan terhadap Reaksi Investor. Jurnal KLH, (401): 1-17.

Ramadhani, I. A. (2016). Pengaruh Pengungkapan Sustainability Report terhadap Nilai Perusahaan dengan Profitabilitas sebagai Moderasi. Jurnal Ilmiah Mahasiswa FEB, 4(2). 
Simbolon, J., dan Sueb, M. (2016). Pengaruh Pengungkapan Sustainability Report terhadap Kinerja Keuangan Perusahaan (Studi Empiris pada Perusahaan yang Terdaftar dalam Bursa Efek Indonesia). Simposium Nasional Akuntansi XIX, Lampung, 1-30.

Suchman, M. C. (1995). Managing Legitimacy: Strategic and Institutional Approaches. Academy of Management Review, 20(3): 571-610. Doi:10.5465/AMR.1995.9508080331.

Sudiyatno, B., dan Puspitasari, E. (2010). Tobin's Q dan Altman Z-Score sebagai Indikator Pengukuran Kinerja Perusahaan. Kajian Akuntansi, ISSN: 19794886, 2(1): 9-21.

Sustainability Reporting Award (SRA). Diakses Juli dan November 2017, dari http://sra.ncsr-id.org/.

Tarigan, J., dan Semuel, H. (2015). Pengungkapan Sustainability Report dan Kinerja Keuangan. Jurnal Akuntansi dan Keuangan, 16(2): 88-101. Doi:10.9744/jak.16.2.88-101

Tilling, M. V. (2004). Refinements to Legitimacy Theory in Social and Environmental Accounting. Commerce Research Paper Series, 6(4): 1-11.

WCED. (1987). Our Common Future: Report of the World Commission on Environment and Development. Medicine, Conflict and Survival, 4(1): 300. Doi:10.1080/07488008808408783.

Webb, K. A., Cahan, S., dan Sun, J. (2008). The Effect of Globalization and Legal Environment on Voluntary Disclosure, 43: 219-245.

Weber, O., Koellner, T., Habegger, D., Steffensen, H., dan Ohnemus, P. (2008). The Relation between the GRI Indicators and the Financial Performance of Firms. Progress in Industrial Ecology - An International Journal, 5(3): 236-254. Doi:10.1504/PIE.2008.019127 